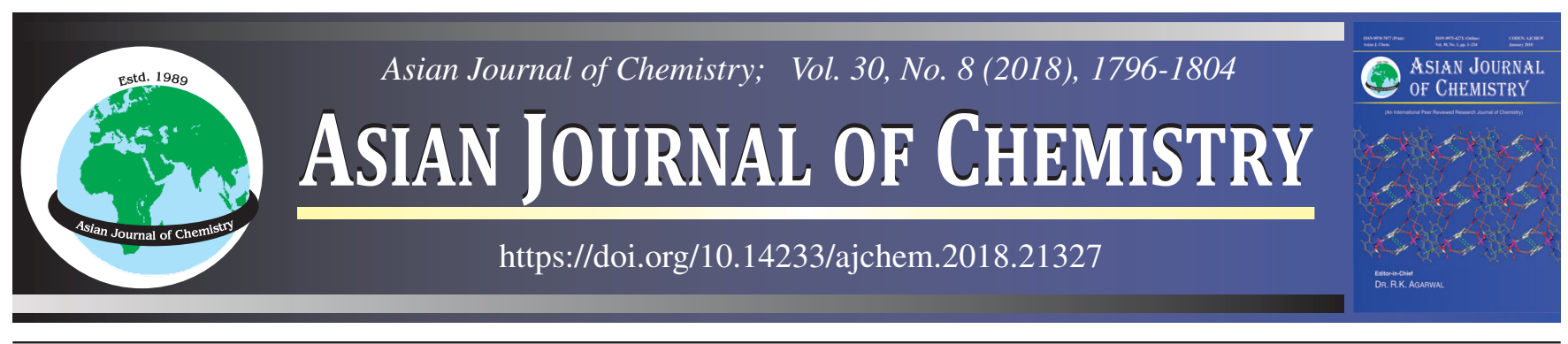

\title{
Effect of Alkyl Group/s and Type of Aromatic Conjugation on Transalkylation Reactions of Alkyl Aromatics
}

\section{K. MoKoena ${ }^{1}$ and M.S. SCURRELL ${ }^{2, *}$}

${ }^{1}$ Molecular Sciences Institute, School of Chemistry, University of Witwatersrand, Braamfontein, Johannesburg, 2050 South Africa ${ }^{2}$ Department of Civil and Chemical Engineering, University of South Africa, Florida, Johannesburg, 1710 South Africa

*Corresponding author: E-mail: scurrms@unisa.ac.za

Received: 12 March 2018;

Accepted: 13 June 2018;

Published online: 30 June 2018;

AJC-18977

Alkyl group removal (not necessarily transalkylation) from the aromatic ring favoured sterically strained molecules and if there is less strain then removal from the ring with the most alkyl groups is favoured over considerations of the alkyl group size. The amount and type of aromatic ring conjugation also plays an important role in the alkyl-transfer reactions of alkylaromatics. The position of the alkyl group on the aromatic moiety also affects alkyl-transfer due to both electronic effects and more importantly the steric factors. Contrary to the ease of dealkylation or alkyl group removal favouring conjugation, alkylation or alkyl group acceptance favoured smaller aromatics or reduced conjugation. With the above observations in mind and the fact that the ease of alkyl group removal increased with aromatic conjugation and considering the fact that benzene derivatives required stronger acid sites for activation. The calculations suggest that use of less acidic large pore zeolites like MCM-41 and MCM-48 might result in a selective one-way (no reverse reactions) alkyl-transfer from bulky molecules to smaller benzene derivatives.

Keywords: Alkylbenzene, Transalkylation, Disportionation, Zeolites, DFT calculations, Mesoporous materials, Catalysis.

\section{INTRODUCTION}

The potential of Al-MCM-41 in catalyzing alkyl-transfer reactions of alkylaromatics will be dealt in this paper, where ethylbenzene and mesitylene disproportionation reactions are considered. Reactions of alkylbenzenes are of great scientific and industrial interest [1-4].

The usual catalysts of choice are high acidity zeolites, such as mordenite and near-faujasite zeolites, especially HY [5-7]. Mesitylene-benzene reactions on these two zeolites have recently showed aspects of the detailed mechanism prevailing in transalkylation reactions, including disportionation [8]. The mesoporous materials show very weak acid site strengths as compared with mordenite and LZY-82, but are still catalysts of interest since it was also earlier concluded that the ease of alkyl-transfer reaction increases with the number, chain length and type of an alkyl group/s on the aromatic ring. This led to selecting these catalytic materials as good candidates in reactions involving bulky molecules (polyalkyl species) owing to their very large pores. The alkyl-transfer study was greatly supplemented by the work which has now been conducted involving the calculation of the thermodynamic values of trans-alkylation reactions of alkyl-aromatics including polynuclear and heteroatomic aromatics. There were unexpected discrepancies between results of the current study and the calculated thermodynamic values mainly due to the fact that catalytic interactions were not taken into considerations during the calculations. However, the calculations do suggest that lower acidity materials be seriously considered as candidate systems for the transformation of alkylaromatics.

\section{EXPERIMENTAL}

Thermodynamic calculations of alkyl-transfer reactions were carried out at SASOL using the DMol3 density functional theory (DFT) code from Accelrys, Inc. In evaluating at the effect of the type of an alkyl group on the aromatic ring on trans-alkylation reactions three alkylbenzenes were used, all with the formula $\mathrm{C}_{9} \mathrm{H}_{12}$ (Scheme-I), i.e. mesitylene $(1.1,1.2)$, cumene $(2.1,2.2)$ and $n$-propylbenzene $(3.1,3.2)$. Other reaction conditions were kept constant.

\section{RESULTS AND DISCUSSION}

Alkyl-transfer reactions: Disproportionation of mesitylene was less than $75 \%$ (Fig. 1), cumene conversion reached $100 \%$ during the initial stages of the reaction and propylbenzene conversion reached $95 \%$ on both mordenite and LZY-82; lower conversions were observed on Al-MCM-41 (*4 and $* 5)$. The 
<smiles>Cc1cc(C)cc(Cc2c(C)cc(C)cc2C)c1</smiles><smiles>Cc1cc(C)cc(C)c1</smiles><smiles>CC(C)c1ccc(C(C)C)cc1</smiles><smiles>CC(C)c1ccc(C(C)C)cc1</smiles><smiles>CCCc1ccccc1</smiles><smiles>CCCc1ccc(CCCc2ccccc2)cc1</smiles><smiles>CCCc1ccc(-c2ccc(CCC)cc2)cc1</smiles> 

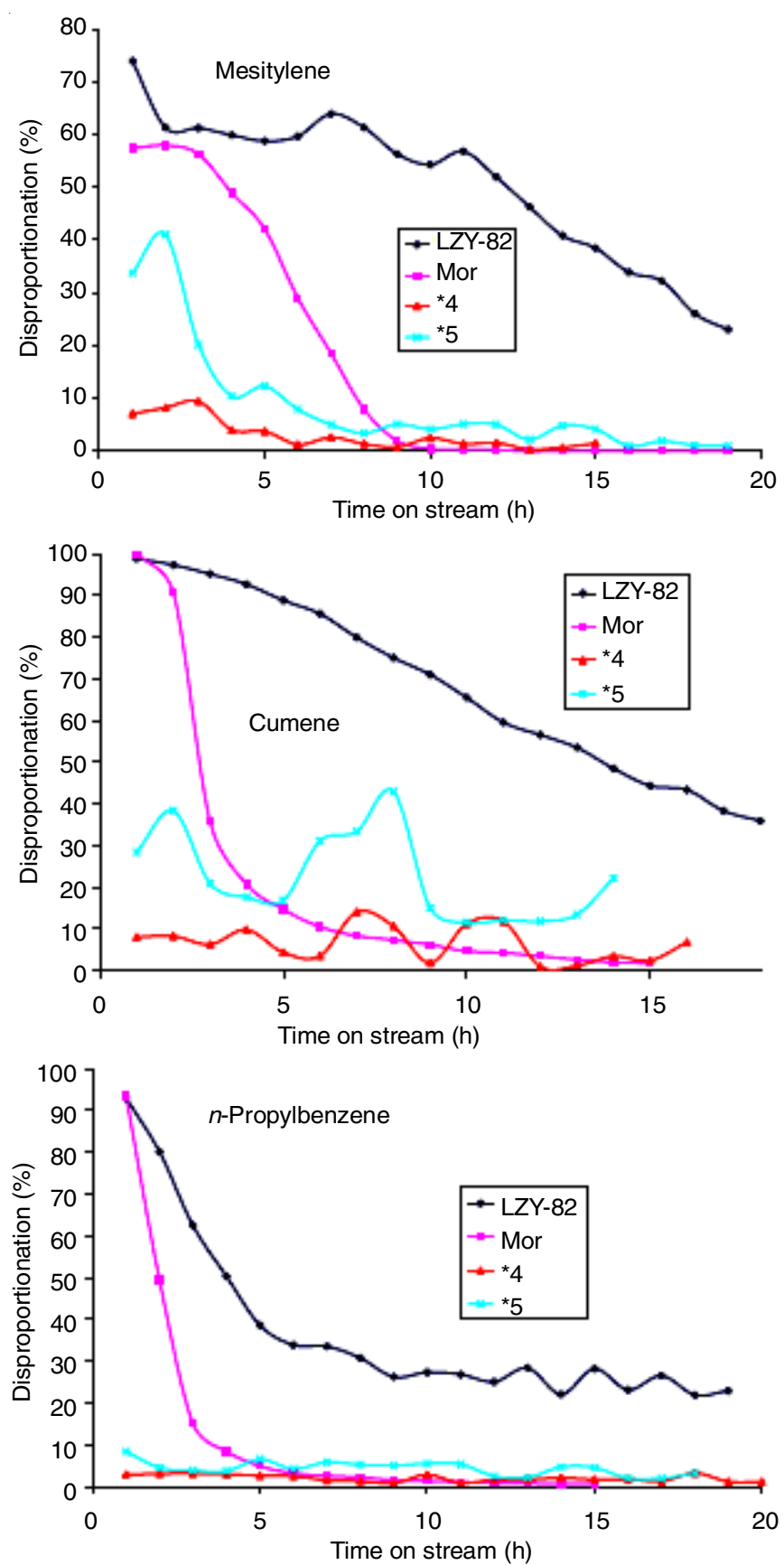

Fig. 1. Alkylbenzene disproportionation traces with time on stream (mol $\%$ ) at $300{ }^{\circ} \mathrm{C}$

observed high conversions on acidic zeolites (mordenite and LZY-82) though very much attributed to stronger catalytic acid sites, were also due to: 1) more than one reaction pathway $[2.1,2.2,3.1$ and 3.2 (Scheme-I)], 2) the ease with which the alkyl-group is cleaved off from the ring and 3) the stability of the carbenium ion that formed. The ease of alkyl group cleavage was much related to the stability of the carbenium ion. The carbenium ion $\mathrm{CH}_{3}-\mathrm{CH}^{+}-\mathrm{CH}_{3}$ [Scheme-I (2.2)] was the most stable one because it had two alkyl groups $\left(\mathrm{CH}_{3}\right)$ which better balanced out the positive charge on the middle carbon. The $\mathrm{CH}_{2}{ }^{+}-\mathrm{CH}_{2}-\mathrm{CH}_{3}$ [Scheme-I (3.2)] ion was less stable since it had only one alkyl group $\left(\mathrm{CH}_{2} \mathrm{CH}_{3}\right)$ stabilizing the charge while the $\mathrm{CH}_{3}{ }^{+}$[Scheme-I (1.2)] carbenium ion was the least stable and as a result there was probably one route towards the alkyl- transfer reactions [Scheme-I (1.1 not 1.2)], namely, the bimolecular option. The other factor which might have favoured high conversions was probably the lack of a reverse reaction for cumene and propylbenzene, i.e. the products formed were mainly diisopropylbenzenes and di- $n$-propylbenzenes. Both were very bulky and as a result accessing active sites became a problem, as earlier concluded, and consequently they were not involved in further reactions. The simplest explanation for high conversions would be: for mesitylene to disproportionate, two molecules had to be involved while for cumene and propylbenzene one molecule was sufficient to contribute towards conversion (not necessarily disproportionation). The fact that reversible reactions were responsible for a reduced contribution from disproportionation was supported by higher disproportionation for mesitylene than propylbenzene on the less acidic Al-MCM-41 and this is better depicted in Fig. 2. This suggested that mesitylene underwent disproportionation more easily than propylbenzene and that the dealkylationrealkylation route [Scheme-I (3.2)] required strong acid sites (mainly for the dealkylation reaction). What seemed to be competing with mesitylene was cumene. Though dealkylation required strong sites; steric effects played an important role in the cleavage of the alkyl group. These steric effects were higher for cumene with two $\mathrm{CH}_{3}$ groups closer to the aromatic ring and due to repulsion forces between the ring and the alkyl groups dealkylation was favoured. $n$-Propylbenzene exhibited lower steric effects to such an extent that dealkylation or alkyl group cleavage relied solely on the acid site strength of the catalyst.
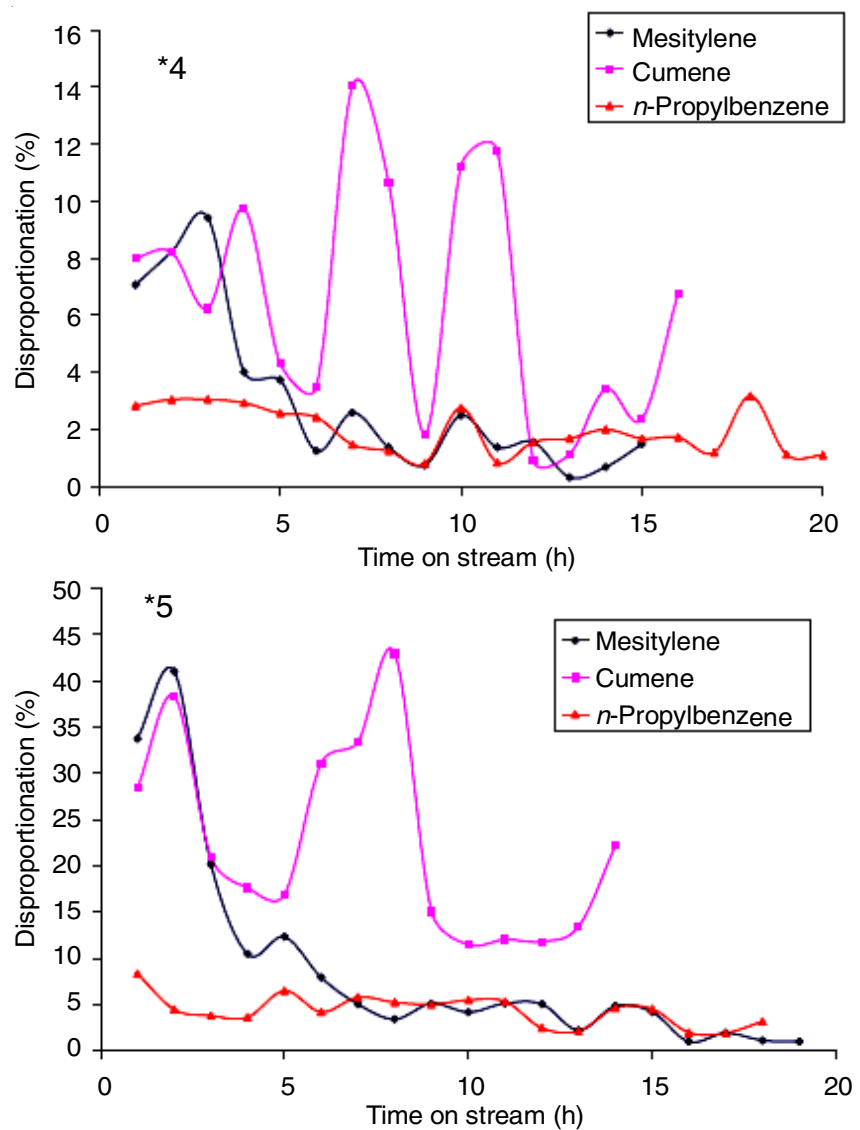

Fig. 2. Alkylbenzene disproportionation with time on stream (mol \%) on Al-MCM- 41 at $300{ }^{\circ} \mathrm{C}$ 
The other noteworthy feature of Fig. 2 is that the mesitylene trace showed stronger catalytic deactivation than other molecules probably due to the fact that mesitylene disproportionation formed xylene and tetra-methylbenzene; hence with the decrease in the number of alkyl groups on the ring for xylene, disproportionation was difficult and most probably strong adsorption on the active sites was favoured resulting in blockage of active sites and deactivation. Due to this quick deactivation and the observed high disproportionation tendency for cumene, mesitylene was rated less reactive and the order of reactivity is shown in Fig. 3. This showed that the order of reactivity favoured the sterically constrained molecules and for the less constrained molecules the number of alkyl groups on the ring was the determining factor compared to the alkyl group chain length.
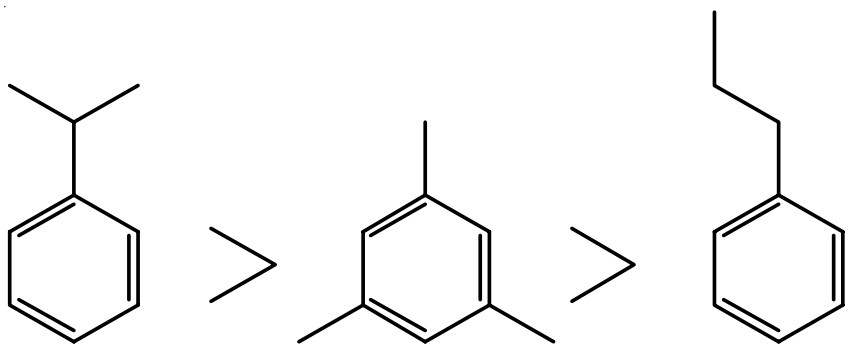

Fig. 3. Effects of alkyl group/s on the reactivity of alkyl-aromatics

The observed chaotic behaviour in Fig. 2 was attributed to polymerization and subsequent cracking reactions in the zeolite pores as explained elsewhere [8] where mesitylene showed the same behaviour at higher temperatures $\left(500{ }^{\circ} \mathrm{C}\right)$. As expected, disproportionation depended on the amount of $\mathrm{Al}$ atoms in the framework structure of the zeolite, i.e. *5 (Si/Al $=9.9)$ showed better activities than $* 4(\mathrm{Si} / \mathrm{Al}=30)$.

Thermodynamic calculations: Thermodynamic calculations showed the following values for transalkylation between alkyl-naphthalenes and benzene:
There seems to be a break in the trend of $\Delta \mathrm{G}$ values from reaction 1 to 3 in Scheme-II, since one would expect reaction 2 to have a value close to $-3.5 \mathrm{~kJ} \mathrm{~mol}^{-1}$ and not more than the value of reaction 1. If catalytic interactions (constraints) were taken into consideration, the value for reaction 2 would be acceptable but then that of reaction 3 would be out of order if one considers molecular size restrictions. The above results did not agree well with the fact that the stability of the carbenium ion increases with the chain length of the alkyl group and that the ease of cleavage of such groups increases accordingly. Similar reactions from alkyl-transfer studies were compared to the above results and Scheme-III shows typical reactions that were looked at. Though these reactions were catalyzed by acidic mordenite and LZY-82, presumably, similar results should be observed on AL-MCM-41, since all three molecules were monoalkylbenzenes. The graphs in Fig. 4 are of course from different temperatures but noticeable was the behaviour of toluene with respect to ethylbenzene. Ethylbenzene with one extra carbon atom on the alkyl group showed much higher reactivities than toluene even though its disproportionation was performed at lower temperatures than used for toluene.

Studies on alkyl-transfer reactions have shown an increase in disproportionation with temperature but ethylbenzene was certainly more reactive than toluene and this agrees well with previous conclusions on the type of alkyl groups in transalkylation reactions. From the above discussion, it became difficult to accept the thermodynamic values presented here.

Very interesting and important results from the calculations are shown in Schemes IV and $\mathbf{V}$. The first set of values (1) on Scheme-IV showed that with increase in conjugation (number of aromatic rings fused together) there was a corresponding increase in the ease of alkyl group removal (cleavage) from the rings. The indicated values are an average of the $\Delta \mathrm{G}$ values for the removal of a methyl group from any position on a particular aromatic conjugation. These values increased from $-14.6 \mathrm{~kJ} \mathrm{~mol}^{-1}$ for phenanthrene derivatives to $-4.8 \mathrm{~kJ} \mathrm{~mol}^{-1}$ of the pirene derivatives indicating that even though there was

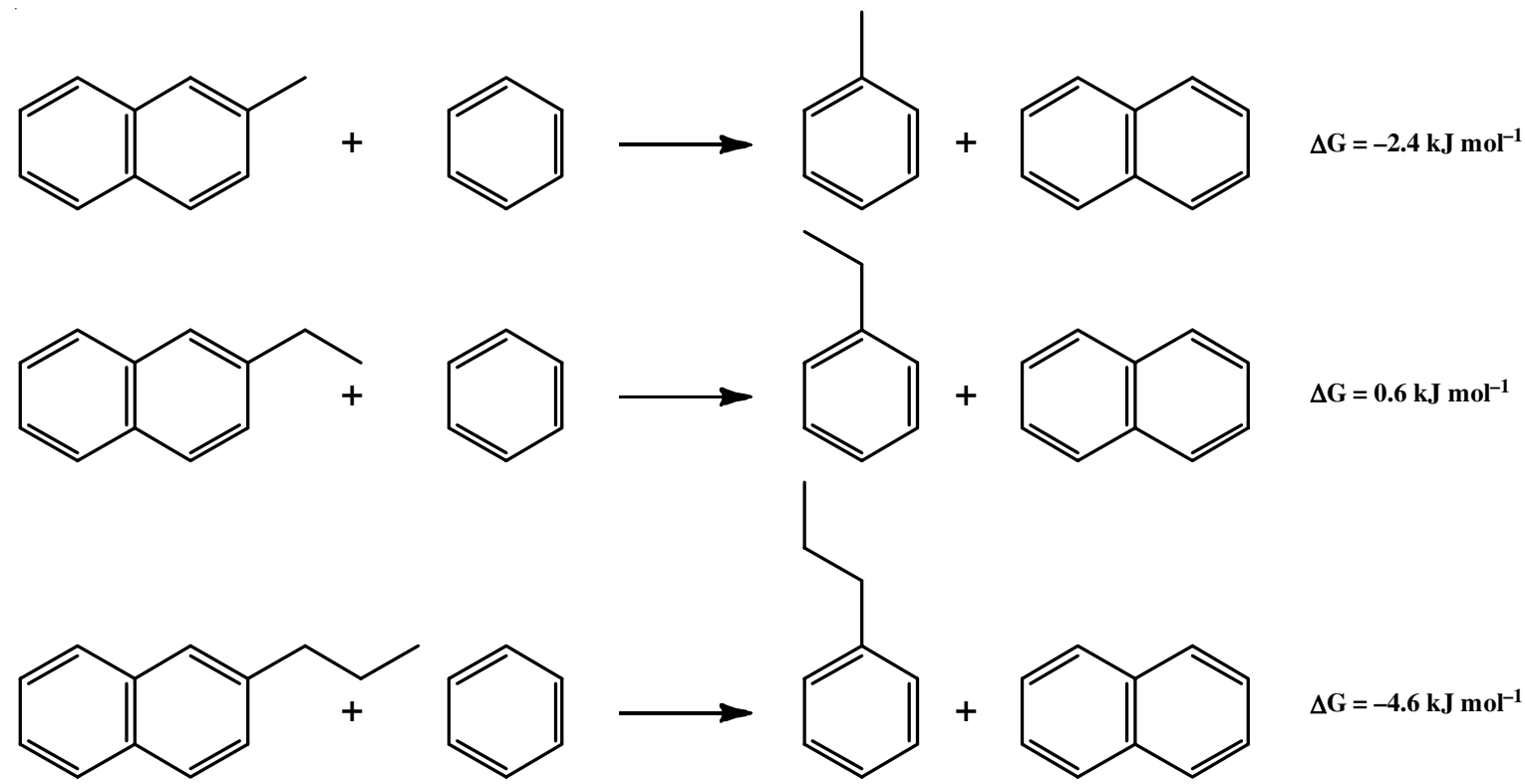

Scheme-II: Thermodynamic values of transalkylation reactions between alkylnaphthalenes and benzene 
<smiles>CCCc1ccc(CCC)cc1</smiles>

Scheme-III: Disproportionation reactions of alkylbenzenes

an increase in conjugation, the type of conjugation also played a significant role and the same was shown by the large gap between the $\Delta \mathrm{G}$ values of anthracenic and phenanthrenic derivatives, both of which consist of three rings.

The second set of values (2) in Scheme-IV showed again an unexpected break in the decrease in $\Delta \mathrm{G}$ values with respect to only one type of conjugation and similar methyl group position. The expected value would be close to $-3.8 \mathrm{~kJ} \mathrm{~mol}^{-1}$ for anthracenic derivatives. The low value for tetracene suggested that there was some stability with increase in conjugation
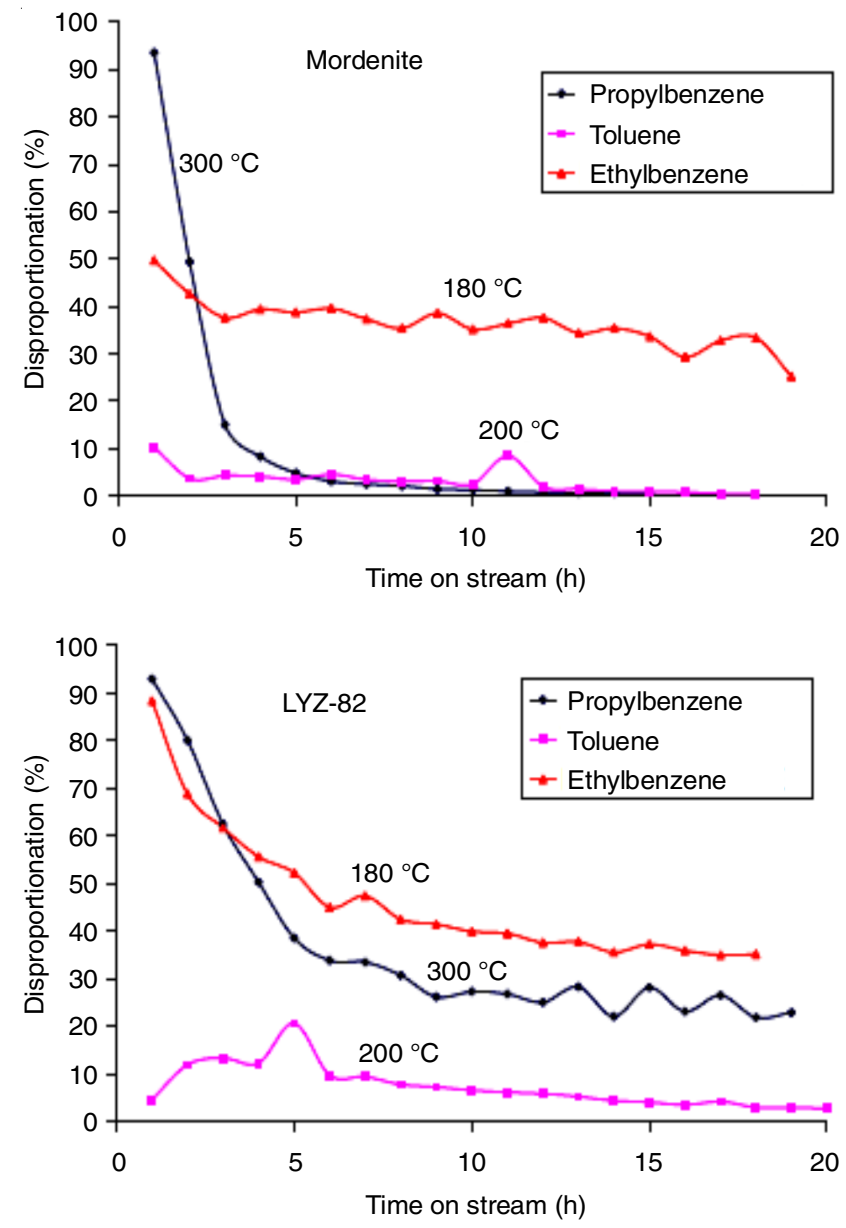

Fig. 4. Disproportionation traces of alkylbenzenes ( $\mathrm{mol} \%)$<smiles>c1ccccc1</smiles>
$+$<smiles>c1ccc2ccccc2c1</smiles><smiles>C[13CH3]</smiles><smiles>c1ccccc1</smiles>
$+$<smiles>c1ccc2cc3ccccc3cc2c1</smiles>
2<smiles>C1CCCC1</smiles><smiles>c1ccccc1</smiles>
$+$<smiles>c1ccc2cc3ccccc3cc2c1</smiles><smiles>c1ccc2c(c1)ccc1ccccc12</smiles><smiles>[CH]1CCC1</smiles><smiles>Cc1ccccc1</smiles>

$+$<smiles>c1ccc2c(c1)ccc1ccccc12</smiles>

$\Delta \mathrm{G} \sim-8.1 \mathrm{~kJ} \mathrm{~mol}^{-1}$

$\Delta \mathbf{G} \sim-2.7 \mathrm{~kJ} \mathrm{~mol}^{-1}$

$\Delta \mathrm{G} \sim-14.6 \mathrm{~kJ} \mathrm{~mol}^{-1}$

$+$<smiles>Cc1ccccc1</smiles><smiles>Cc1ccc2c3c(ccc(C)c13)CC=C2</smiles><smiles>Cc1ccccc1</smiles>

$\Delta \mathrm{G} \sim-4.8 \mathrm{~kJ} \mathrm{~mol}^{-1}$ 
$\longrightarrow \longrightarrow$

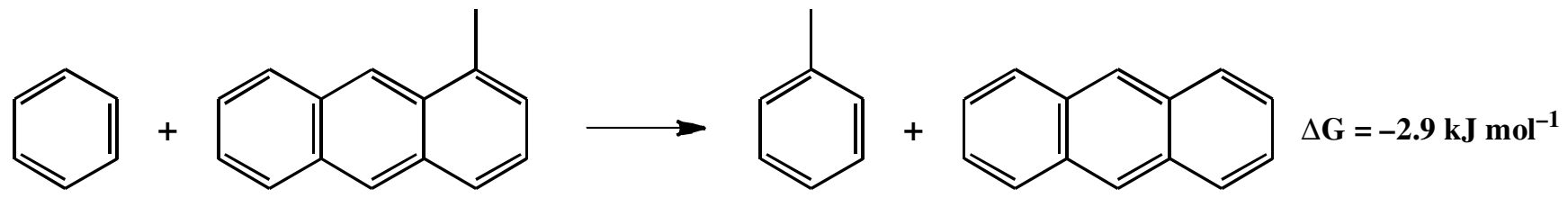<smiles></smiles>

Scheme-IV: Thermodynamic values showing the effect of conjugation on transalkylation to benzene: $1=$ naphthalenic, $2=$ anthracenic, $3=$ phenanthrenic, $4=$ pirenic, 5 = tetracenic derivatives<smiles>Cc1c2ccccc2cc2ccccc12</smiles><smiles>Cc1ccccc1</smiles>
$+$<smiles>c1ccccc1</smiles><smiles>c1ccc2ccccc2c1</smiles><smiles>c1ccc2ccccc2c1</smiles><smiles>c1ccc2cc3ccccc3cc2c1</smiles>

$\Delta \mathbf{G}=-\mathbf{1 5 . 6} \mathrm{kJ} \mathrm{mol}^{-1}$<smiles>Cc1cccc2cc3ccccc3cc12</smiles><smiles>c1ccccc1</smiles><smiles>Cc1ccccc1</smiles>
$+$<smiles>c1ccc2ccccc2c1</smiles><smiles>CCCCCCCC</smiles><smiles>c1ccc2ccccc2c1</smiles><smiles>c1ccc2cc3ccccc3cc2c1</smiles>

$\Delta \mathbf{G}=0.1 \mathrm{~kJ} \mathrm{~mol}^{-1}$<smiles>Cc1ccc2cc3ccccc3cc2c1</smiles><smiles>c1ccccc1</smiles><smiles>Cc1ccccc1</smiles><smiles>CC=CC</smiles><smiles>c1ccc2cc3ccccc3cc2c1</smiles>
$\Delta \mathbf{G}=-3.0 \mathrm{~kJ} \mathrm{~mol} \mathbf{~}^{-1}$<smiles>c1ccc2ccccc2c1</smiles><smiles>c1ccc2ccccc2c1</smiles><smiles>c1ccc2cc3ccccc3cc2c1</smiles>

$\Delta G=0.0 \mathrm{~kJ} \mathrm{~mol}^{-1}$

Scheme-V: Thermodynamic values showing the effect of an alkyl acceptor (in absence of catalytic interactions) on transalkylation reactions 
which resulted in the methyl group being less bound to the rings. From the values observed in Scheme-IV it was concluded that the ease of alkyl group removal increased with the amount and type of conjugation of the alkylaromatic species even though the trend in thermodynamic values was not always as expected.

This was important since aromatic molecular size increases with conjugation and this would obviously lead to the need to use large pore zeolites for their transformations. The larger the pores of these catalysts the less acidic are the active sites that catalyze transalkylation reactions. This would be supplemented by the increase in the ease of alkyl group removal, which accompanies an increase in the molecular size of the alkylaromatics.

Thermodynamic values in $\mathbf{S c h e m e - V}$ shows a comparison of the abilities or strengths with which the alkyl-acceptor accepts or removes (in case of a bimolecular system) the alkyl group from a conjugated system. In all cases shown in Scheme$\mathbf{V}$, benzene certainly is a better acceptor than naphthalene; and since the $\Delta \mathrm{G}$ value for transalkylation from methylnaphthalene to benzene is negative (Scheme-IV), presumably this could mean that transalkylation would prefer alkylation of smaller rings (with lower conjugation). With the above being true, the question of whether the alkyl group of an alkyl-naphthalene would preferably transfer to benzene or anthracene in such a mixture (Scheme-VI) would be answered.

The study also involved calculations involving bulky aromatics, non-alkyl substituents and heteroatomic aromatics (Schemes VII and VIII).

\section{Conclusion}

The study has shown that alkyl group removal (not necessarily transalkylation) from the aromatic ring favoured sterically stressed molecules and if there is less stress then removal

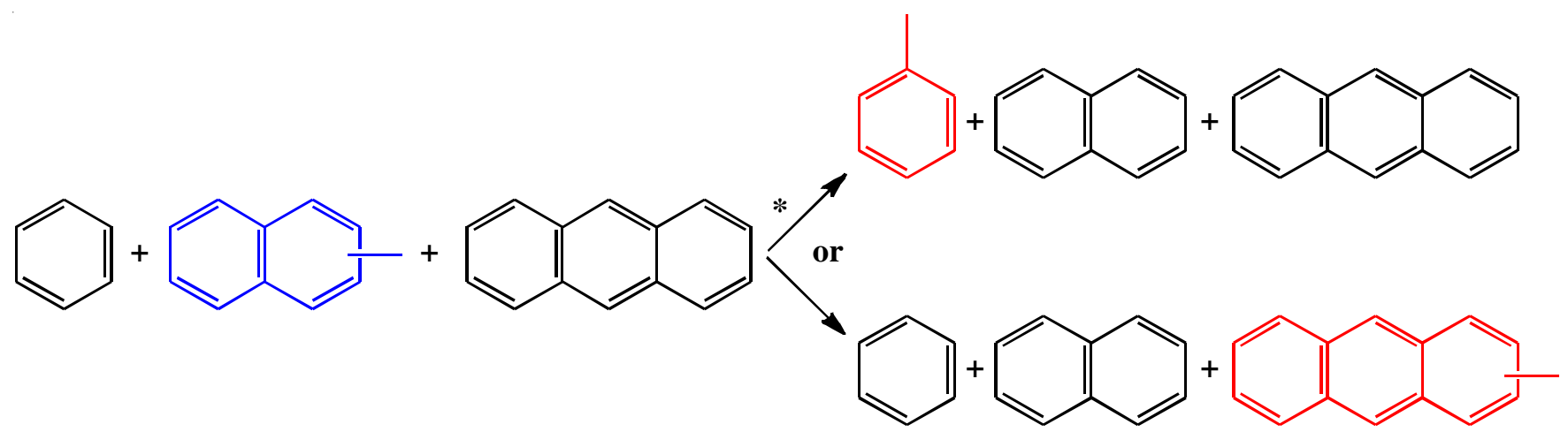

Scheme-VI: Preference of transalkylation in aromatics: * $=$ preferred route<smiles>Cc1c(O)ccc2ccccc12</smiles><smiles>c1ccccc1</smiles><smiles>Cc1ccccc1</smiles><smiles>Oc1ccc2ccccc2c1</smiles>

$\Delta \mathbf{G}=-11.6 \mathrm{~kJ} \mathrm{~mol}^{-1}$<smiles>Cc1cccc2cccc(O)c12</smiles><smiles>c1ccccc1</smiles><smiles>C=C</smiles><smiles>Cc1ccccc1</smiles>

$\Delta G=-19.3 \mathrm{~kJ} \mathrm{~mol}^{-1}$<smiles>Cc1c([N+](=O)[O-])ccc2ccccc12</smiles><smiles>c1ccccc1</smiles><smiles>Cc1ccccc1</smiles><smiles>O=[N+]([O-])c1ccc2ccccc2c1</smiles>

$\Delta G=-31.7 \mathrm{~kJ} \mathrm{~mol}^{-1}$<smiles>Cc1cccc2cccc([N+](=O)[O-])c12</smiles><smiles>CC1=CC=CCC1</smiles><smiles>O=[N+]([O-])c1cccc2ccccc12</smiles>

Scheme-VII: Thermodynamic values indicating the effect of non-alkyl substituents on transalkylation 
$\longrightarrow \Delta \rightarrow$<smiles>C[C+](C)c1ccc2ccccc2c1</smiles><smiles>CCCc1ccc2ccccc2c1</smiles><smiles>CC(C)(C)c1ccc2ccccc2c1</smiles>

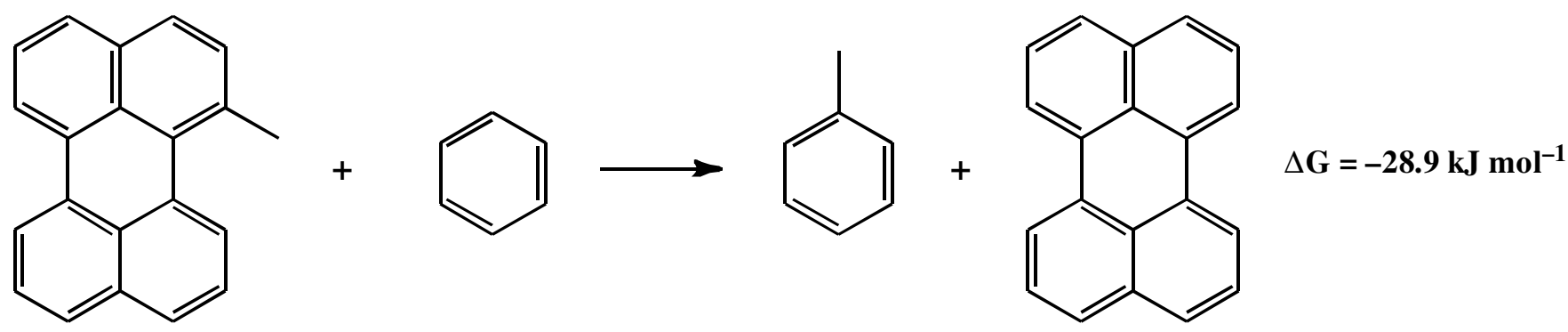<smiles>Cc1ccc2cccnc2c1</smiles><smiles>Cc1ccccc1-c1ccccc1</smiles><smiles>Cc1ccccc1-c1ccccc1</smiles>
Scheme-VIII: Thermodynamic values for transalkylation between benzene and alkyl/alkyl-heteroatomic aromatics 
from the ring with the most alkyl groups is favoured over considerations of the alkyl group size. It had been concluded earlier that the ease of alkyl group removal increased with the number, chain length and type of an alkyl group. In addition to this, the present work shows that the amount and type of aromatic ring conjugation also plays an important role in the alkyl-transfer reactions of alkylaromatics. The position of the alkyl group on the aromatic moiety also affects alkyl-transfer due to both electronic effects and more importantly, the steric factors. Contrary to the ease of dealkylation or alkyl group removal favouring conjugation, alkylation or alkyl group acceptance favoured smaller aromatics or reduced conjugation. With the above observations in mind and the fact that the ease of alkyl group removal increased with aromatic conjugation and considering the fact that benzenic derivatives required stronger acid sites for activation, the use of less acidic large pore zeolites such as MCM-41 and MCM-48 might result in a selective oneway (no reverse reactions) alkyl-transfer from bulky molecules to smaller benzenic derivatives (as is shown in the follow-up work).

\section{ACKNOWLEDGEMENTS}

One of the authors (K. Mokoena) is grateful for financial support shown by Sasol Technology Research and Development.

\section{REFERENCES}

1. C. Perego and P. Pollesel, Adv. Nanopor. Mater, 1, 97 (2010); https://doi.org/10.1016/S1878-7959(09)00102-9.

2. A.L. Kustov, A.N. Kalenchuk, V.V. Lunin, A.E. Koklin and V.I. Bogdan, Russ. J. Phys. Chem. B, 10, 1131 (2016); https://doi.org/10.1134/S1990793116070113.

3. P.V. Naumkin, T.N. Nesterova, I.A. Nesterov, A.M. Toikka and V.A. Shakun, Ind. Eng. Chem. Chem. Res., 54, 8629 (2015); https://doi.org/10.1021/acs.iecr.5b02021.

4. S. Al-Khattaf, S.A. Ali, A.M. Aitani, N. Zilková, D. Kubieka and J. Eejka, Catal. Rev., Sci. Eng., 56, 333 (2014); https://doi.org/10.1080/01614940.2014.946846.

5. S.-T. Tsai, F.-H. Chao, I. Wang and T.C. Tsai, Appl. Catal. A Gen., 385, 73 (2010); https://doi.org/10.1016/j.apcata.2010.06.047.

6. G.M. Lari, K. Desai, C. Mondelli and J. Pérez-Ramírez, Catal. Sci. Technol., 6, 2706 (2016); https://doi.org/10.1039/C5CY02020D.

7. H. Chen, Q. Wang, X. Zhang and L. Wang, Appl. Catal. B, 166-167, 327 (2015); https://doi.org/10.1016/i.apcatb.2014.11.041.

8. K. Mokoena and M.S. Scurrell, Micropor. Mesopor. Mater, 241, 28 (2017); https://doi.org/10.1016/j.micromeso.2016.12.012. 